\title{
Living together in the night: abundance and habitat use of sympatric and allopatric populations of slow lorises and tarsiers
}

\author{
R. A. Munds ${ }^{1, *}$, R. Ali ${ }^{2,3}$, V. Nijman ${ }^{4}$, K. A. I. Nekaris ${ }^{4}$, B. Goossens ${ }^{2,5}$ \\ ${ }^{1}$ University of Missouri, Department of Anthropology, 107 Swallow Hall, Columbia, Missouri 65203, USA \\ ${ }^{2}$ Danau Girang Field Centre, c/o Sabah Wildlife Department, Wisma Muis, 88100 Kota Kinabalu, Sabah, Malaysia \\ ${ }^{3}$ Centre for Primate Studies Borneo, Institute for Tropical Biology and Conservation, Universiti Malaysia Sabah, \\ 88999 Kota Kinabalu, Sabah, Malaysia \\ ${ }^{4}$ Oxford Brookes University, Department of Anthropology and Geography, Nocturnal Primate Research Group, \\ Oxford OX3 0BP, UK
}

${ }^{5}$ Organisms and Environment Division, Cardiff School of Biosciences, Cardiff University, Biomedical Sciences Building, Museum Avenue, Cardiff CF10 3AX, UK

\begin{abstract}
Throughout much of Asia, slow lorises (Nycticebus) and tarsiers (Tarsius) live allopatrically, but on several islands, including Sumatra and Borneo, they occur in sympatry. Dwindling habitats could result in resource competition within these sympatric populations, as the diets of these species overlap. To assess the possibility of resource competition, we gathered data from the literature on the abundance and microhabitat structure of slow loris and tarsier species throughout their ranges. We also estimated abundances of Bornean lorises Nycticebus menagensis and western tarsiers Tarsius bancanus borneanus and investigated their habitat use in Sabah, Malaysian Borneo. We predicted that species living sympatrically would favor different heights, and thus different microhabitat structures from congeners, and have lower abundances compared with allopatric species because of limiting factors. Across their ranges, loris density did not vary regardless of whether they were allopatric or sympatric. However, across sympatric and allopatric tarsier ranges, there were significant differences in densities (sympatric: 3-27 ind. $\mathrm{km}^{-2}$, allopatric: $57-268$ ind. $\mathrm{km}^{-2}$ ). Microhabitat use varied significantly between sympatric and allopatric loris populations $(p=0.036)$ but not between sympatric and allopatric tarsier populations. Our results, although based on a limited amount of data, suggest that tarsiers are impacted by the presence of slow lorises in their habits, and these populations should be monitored, especially as habitat sizes dwindle and resources continue to become scarce.
\end{abstract}

KEY WORDS: Sympatry $\cdot$ Allopatry $\cdot$ Niche divergence $\cdot$ Intergeneric competition

\section{INTRODUCTION}

Studies on Asian nocturnal primates, the lorises and tarsiers, are still lacking, despite the importance of understanding the behavior and ecology of these species for conservation. This is partially due to the taxonomic compexity of slow lorises and tarsiers.
Only in the past 2 decades was the highly polymorphic slow loris (Nycticebus spp.) split into 8 species $(N$. bengalensis, $N$. coucang, $N$. javanicus, N. menagensis, N. pygmaeus, $N$. bancanus, $N$. borneanus, $N$. kayan) (Groves 1998, Ravosa 1998, Roos 2003, Chen et al. 2006, Munds et al. 2013). Over a similar period of time, the number of tarsier species has increased 
from 3 to 11 (Niemitz 1984, Musser \& Dagasto 1987, Shekelle et al. 2008), suggesting that further taxonomic divisions are possible at the species and even genus levels (Shekelle \& Salim 2009, Groves \& Shekelle 2010); we should note here that we use the single genus classification for tarsiers as found on the IUCN Red List (IUCN 2013). Our understanding of the taxonomy of these primates is improving, but it emphasizes how little we know about these species. Research on their abundance, habitat use and other behavioral ecological aspects is required to be able to conserve these nocturnal primates.

For the most part, slow lorises and tarsiers have an allopatric distribution (Gursky 2007, Nekaris \& Bearder 2007). Slow lorises are distributed in mainland Southeast Asia, from northeastern India and southern China south to the Thai-Malay Peninsula, and further south onto the Sunda Shelf Islands of Sumatra, Borneo and Java, whereas tarsiers have an insular distribution further to the east. One species of tarsier is found on the southern Philippine Islands, several species occur on Sulawesi and offlying islands, and 1 species occurs on Borneo and Sumatra. While there are 2 areas where 2 species of slow loris live sympatrically (i.e. Nycticebus bengalensis and $N$. pygmaeus in Indochina east of the Mekong River, and possibly $N$. menagensis and $N$. kayan in parts of northern Borneo; Munds et al. 2013) and 1 area where 2 species of tarsier live (i.e. Tarsius diana and T. pygmaeus in central Sulawesi), only on Borneo, southern Sumatra and the intervening islands of Bangka and Belitung do we find slow lorises and tarsiers in sympatry (Nijman \& Nekaris 2010). On Banka and Belitung and possibly southwest Borneo, T. bancanus lives sympatrically with $N$. bancanus; on southern Sumatra it lives sympatrically with $N$. coucang; and on different parts of Borneo it lives sympatrically with $N$. menagensis, N. borneanus or N. kayan. While no studies to date address niche overlap in slow lorises and tarsiers, some researchers have suggested intense competition (Harcourt 1999). Both taxa share a similar diet (Jablonski \& Crompton 1994, Ravosa 1998, Nekaris \& Bearder 2007). Bornean slow lorises $N$. menagensis have even been observed attempting to predate on tarsiers (Niemitz 1979). Some argue that because tarsiers are strict undergrowth foragers, most competition is avoided (Niemitz 1984, Crompton \& Andau 1987), but all slow loris species forage at all levels of the forest (Wiens \& Zitzmann 2003, Nekaris et al. 2008, Pliosoengeon \& Savini 2008), suggesting an absence of spatial niche separation.
Here we address whether these primates have evolved niche divergences to lessen intergeneric competition. On a small geographic scale, we focused on the island of Borneo to assess whether slow loris and tarsier microhabitats vary based on tree/sapling density and size (diameter at breast height $[\mathrm{DBH}]$ and height). At a larger geographic scale, we evaluated the use of vertical strata by a wide range of slow loris and tarsier species. We hypothesize that in order to reduce competition there will be a difference between observed heights; this would then infer niche separation between tarsiers and slow lorises that live sympatrically. There should be no difference in observed median heights of allopatric species. Additionally, we compare densities of sympatric slow lorises and tarsiers with values from the allopatric populations of these genera. If competition is affecting the sympatric genera, then those populations should have lower densities compared with the allopatric populations.

\section{MATERIALS AND METHODS}

\section{Study site}

The research was conducted in the Lower Kinabatangan Wildlife Sanctuary (LKWS), east Sabah, Malaysian Borneo. The LKWS is composed of 7 different forest types: riverine, seasonally inundated, swamp, limestone, dry dipterocarp, estuary nipa and mangrove (Ancrenaz et al. 2004, Davison 2006). The entire sanctuary spans 26100 ha along both sides of the Kinabatangan River (Goossens et al. 2005, Davison 2006). Data were collected in a 123 ha flat forest area surrounding the Danau Girang Field Centre (DGFC) (elevation 15 m a.s.l.; Fig. 1). The DGFC consists of 2 forest types: semi-inundated and mixed riparian. In some areas the tree density is high, reducing visibility to as little as $2 \mathrm{~m}$. The temperature remains steady all year round (mean ranging between 21 and $34^{\circ} \mathrm{C}$ ). Flooding occurs during the wet season (November-February), precluding data collection, and consequently the study took place during the dry season.

\section{Survey methods and density estimation}

Line-transect surveys were conducted from 17 March to 4 September 2009, between the hours of 18:30 and 02:00. Seven trails and transects were walked a minimum of 4 times, a maximum of 20 , and 


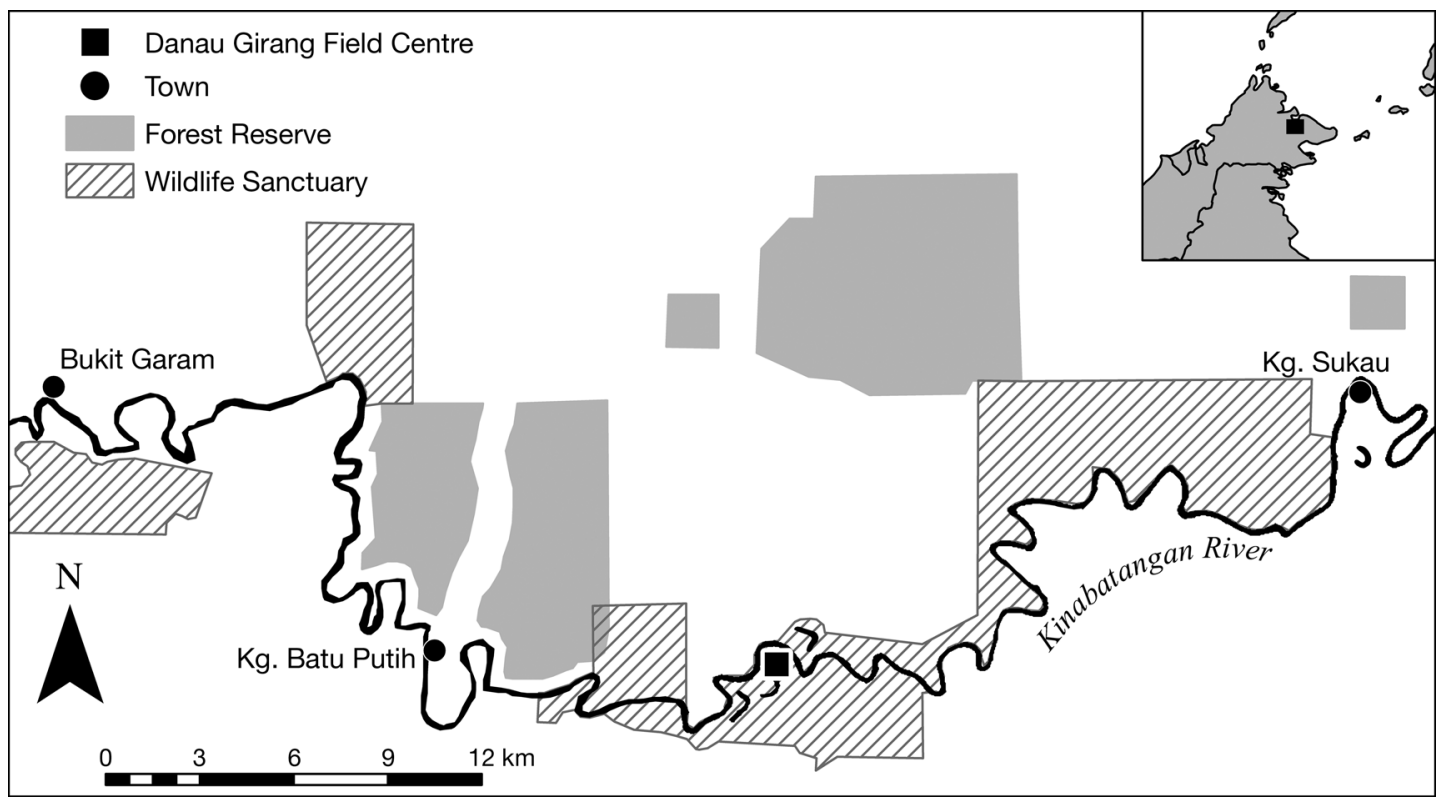

Fig. 1. Danau Girang Field Centre (study site at $05^{\circ} 24^{\prime} 48^{\prime \prime} \mathrm{N}, 118^{\circ} 02^{\prime} 16^{\prime \prime} \mathrm{E}$ ), located in the Lower Kinabatangan Wildlife Sanctuary (LKWS), Sabah, Malaysian Borneo. The reference map in the upper right corner indicates the location of the LKWS in eastern Sabah

an average of 13. Pre-made trails were used to reduce impact on the forest. These trails were predominately straight, which is why we used them for this study. Surveys covered the various habitats of DGFC (Davies 2002) and were typically conducted by 2 people. The average transect/trail length was $1.1 \mathrm{~km}$, walked at $600 \mathrm{~m} \mathrm{~h}^{-1}$. All levels of vegetation were scanned with a Petzl Myo Zoom 4.5 V headlamp, with a mix of red and white filters. Red filters were preferred, as studies indicate that red lights are less disturbing and increase animal observation time (Nekaris 2003, Bearder et al. 2006, Nekaris \& Nijman 2007).

Detection of most nocturnal primates depends on their eye shine, which is produced by a reflective layer of tissue behind the retina known as the tapetum lucidum (Bearder et al. 2006). Slow lorises possess this layer of tissue (Fleagle 1999), unlike tarsiers (Schwartz 2003). Most tarsier studies have focused on the Sulawesi species, which are easily detected by their regular duets during dusk and dawn (Gursky 1998). Western tarsiers are not known to vocalize regularly, making them hard to detect; they were detectable from a red eye glare when a red filter was used.

We collected the following data: number of animals detected on the transect and animal height in the tree. When possible we also recorded the behavior of the animals upon detection.
We calculated density $(D)$ as $D=n / 2 w l$, where $n$ is the number of animals observed, $w$ is the half-width of the trail and $l$ is the length of the trail. The halfwidth of the trail was obtained by eliminating $10 \%$ of the furthest sightings from all observations (Sutherland 2002). Due to the low observation numbers for both primates, the same half-width was used for both.

\section{Microhabitat use}

For Borneo, we used biodegradable flagging tape to mark areas where slow lorises Nycticebus menagensis or tarsiers Tarsius bancanus borneanus were found and we returned later to conduct vegetation samples. We created a $5 \mathrm{~m}$ radius around the trees on which the animals had been spotted. We measured the DBH and height of each tree and sapling in the area that was above $1 \mathrm{~m}$ in height. The measurement of small saplings was necessary because of small DBH and height (Niemitz 1984, Crompton et al. 2010). For comparison, we randomly selected a control group of 6 plots and measured trees in the same manner as described above. To obtain the random sample, we superimposed a grid of $2.5 \mathrm{~cm}$ squares on a map of the field site, and blindly selected plots. In all, 8 loris plots, 6 tarsier plots and 6 neutral plots were examined. 
Across all regions, we collected data on density and habitat use of slow lorises and tarsiers from the literature. Relatively few studies have attempted to estimate densities of these nocturnal primates, and we included only studies that reported densities (as opposed to encounter rates) irrespective of the methodology employed. When densities were reported in groups $\mathrm{km}^{-2}$, we converted this to ind. $\mathrm{km}^{-2}$ using group sizes as reported in the same study, or, if these were not available, group sizes as reported by Gursky (2007). With respect to habitat use we focused on the median height at which slow lorises or tarsiers were observed, provided the studies reported the range of values.

\section{Analysis}

Using a Kolmogorov-Smirnov test, we found our vegetation data were not normally distributed (height, $D=0.2, \mathrm{p}<0.001$ and DBH, $D=0.2, \mathrm{p}<$ 0.001), and generally sample sizes for comparisons were low. We therefore used non-parametric tests throughout. We used the Kruskal-Wallis ANOVA to determine whether variation existed between slow loris, tarsier and neutral habitats. Post hoc MannWhitney $U$-tests were used to test for differences between pairs of habitat types. An additional post hoc test comparing mean ranks to discern deviation was also used, as Mann-Whitney $U$-tests are not always reliable as a post hoc test (Field 2009). To test for differences in densities and height differences between slow lorises and tarsiers living in sympatry or allopatry, we used Mann-Whitney $U$-tests. All tests were run in SPSS v 17.0 with an alpha value of 0.05, 2-tailed.

\section{RESULTS}

\section{Densities and microhabitat use of slow lorises and tarsiers on Borneo}

Our study yielded a survey effort of $68.56 \mathrm{~km}$. The determined half-width for both species combined was $10 \mathrm{~m}$, giving a strip width of $20 \mathrm{~m}$. The range of distances from transect for sightings was 0-27 m, with a median of $3 \mathrm{~m}$. Slow lorises were sighted at greater heights than tarsiers (median height for lorises $=15 \mathrm{~m}$, range $=8.5-30 \mathrm{~m}$; median height for tarsiers $=1.25 \mathrm{~m}$, range $=0.5-3 \mathrm{~m}$ ). Over the study period we saw a total of 8 lorises and 5 tarsiers, resulting in densities of 5.1 lorises $\mathrm{km}^{-2}$ and 3.6 tarsiers $\mathrm{km}^{-2}$.
Comparisons of the loris, tarsier and neutral habitats revealed that heights of trees in the supposed microhabitats of loris (median $=6.8 \mathrm{~m}$, range $=$ 1.3-43.1 $\mathrm{m}$ ) and tarsier (3.6 $\mathrm{m}, 0.8-17.8 \mathrm{~m})$ and in neutral areas $(6.1 \mathrm{~m}, 2-45.3 \mathrm{~m})$ differed significantly $\left(H_{2}=25.92, \mathrm{p}<0.001\right)$. A similar difference was found when comparing tree sizes as measured by DBH with medians of $17.8 \mathrm{~cm}$ for lorises (range $=2.4-74.5 \mathrm{~cm}$ ), $6.2 \mathrm{~cm}$ for tarsiers $(0.04-42 \mathrm{~cm})$ and $12.2 \mathrm{~cm}$ for neutral areas (3.8-50.3 cm; $\left.H_{2}=19.37, \mathrm{p}<0.001\right)$. Tarsier and loris habitats varied significantly in height (Mann-Whitney $U$-test, $U=734.5, \mathrm{p}<0.001$ ) and DBH $(U=877.5, \mathrm{p}<0.001)$. Post hoc analyses indicated that there were no differences between loris and neutral habitats for either height or DBH (MannWhitney $U$-tests: height, $U=968.5, \mathrm{p}=0.758$; $\mathrm{DBH}$, $U=943.5, \mathrm{p}=0.611$ ). Conversely, tarsier and control habitats differed significantly (height, $U=538.5, \mathrm{p}<$ 0.001; DBH, $U=568, \mathrm{p}<0.001)$. Finally, the trees in which lorises and tarsiers were actually recorded differed significantly both in height $(U=0.0, \mathrm{p}<0.001)$ and $\mathrm{DBH}(U=0.0, \mathrm{p}<0.001)$. Tree density was similar in both loris and tarsier microhabitats $(U=8.5, \mathrm{p}=$ $0.421)$. The median number of trees in loris plots was 8 (range $=4-24$ ) and in tarsier plots it was $11(6-16)$.

\section{Densities and microhabitat use of allopatric and sympatric slow lorises and tarsiers}

Seven density estimates were available for 5 species of slow loris, and 9 density estimates were available for 5 species of tarsier (Table 1). In the areas where lorises are allopatric with tarsiers, these estimates ranged from 3 ind. $\mathrm{km}^{-2}$ (Nycticebus bengalensis in Thailand) to 80 ind. $\mathrm{km}^{-2}$ (N. coucang in Malaysia). With a density of 5.1 ind. $\mathrm{km}^{-2}$ for $N$. menagensis, there was no significant difference between densities of slow lorises in areas where they are sympatric or allopatric (Mann-Whitney $U$-test, $U=5, \mathrm{p}=0.571$ ). The range of values for tarsiers was larger than for lorises with low estimates for Tarsius bancanus (3 to 27 ind. $\mathrm{km}^{-2}$ ) and higher estimates for the other species (57 to 268 ind. $\mathrm{km}^{-2}$ ). As such, there is a clear difference between densities of tarsiers in areas where they live allopatrically from lorises (Sulawesi, Philippines) and where they live in sympatry (Borneo, Belitung) (MannWhitney $U$-test, $U=15, \mathrm{p}=0.036)$. We acknowledge that we only have one density estimate for lorises in sympatry with tarsiers, and only 3 estimates for tarsiers in sympatry with lorises, and thus our results should be taken with caution. But these results do highlight differences, especially in the case of tarsiers. 
Table 1. Densities (ind. $\mathrm{km}^{-2}$ ) of allopatric and sympatric slow lorises (Nycticebus) and tarsiers (Tarsius) throughout Southeast Asia. Densities are calculated using different methodologies and are rounded up to the nearest whole number. When a range of habitats was surveyed, only estimates from the least disturbed types were included. n.a.: indicates presence, but no density estimate available

\begin{tabular}{|llccl|}
\hline Area & Species & Nycticebus & Tarsius & Source \\
\hline Slow lorises in allopatry & & & & \\
Cambodia & N. bengalensis & 19 & & Coudrat et al. (2011) \\
Thailand & N. bengalensis & 3 & & Pliosungnoen \& Savini (2008 unpubl.) \\
Thai-Malay Peninsula & N. coucang & 25 & & Johns (1983) \\
Thai-Malay Peninsula & N. coucang & 22 & & Barrett (1984) \\
Thai-Malay Peninsula & N. coucang & 80 & & Wiens \& Zitzman (2003) \\
Java & N. javanicus & 16 & & \\
Slow lorises and tarsiers in ingris et al. (unpubl. data) \\
North Borneo & N. menagensis/T. bancanus & n.a. & 17 & Crompton \& Andau (1986) \\
North Borneo & N. menagensis/T. bancanus & 5 & 3 & Present study \\
Belitung & N. bancanus/T. bancanus & n.a. & 27 & Yustian (2007) \\
Tarsiers in allopatry & T. syrichta & & & \\
Philippines & T. syrichta & & 57 & Neri-Arboleda et al. (2002) \\
Philippines & T. dianae & & 155 & Gursky et al. (2011) \\
Sulawesi & T. dianae & & 268 & Merker et al. (2005) \\
Sulawesi & T. spectrum & & 156 & Gustian et al. (2008) \\
Sulawesi & T. pumilus & 92 & N. Grow (2012 pers. comm.) \\
Sulawesi & & & & \\
\hline
\end{tabular}

Vertical strata use did not differ between populations of tarsiers in areas of sympatry or allopatry (Table 2), irrespective of whether we focused our analysis on median, minimum or maximum reported heights (Mann-Whitney $U$-test, $10<U<14, \mathrm{p}>0.114$ ). In contrast, vertical strata use differed between populations of lorises in areas of sympatry or allopatry (Table 2), and these differences were significant for median and low heights (Mann-Whitney $U$-test, median, $U=18, \mathrm{p}=0.036$; low, $\mathrm{U}=22, \mathrm{p}=0.026$ ) but not for maximum height $(U=19.5, \mathrm{p}=0.102)$. Comparing allopatric populations of lorises and tarsiers, there was no significance in median or maximum heights (Mann-Whitney $U$-test, $22<U<28.5$, p > $0.412)$. Given that in these areas tarsiers are invariably recorded on the ground, there was a small but marked difference between lorises and tarsiers when comparing minimum heights (Mann-Whitney $U$-test, $U=40, \mathrm{p}=0.018$ ) (Fig. 2) .

\section{DISCUSSION}

\section{Abundance of nocturnal primates}

Here we report for the first time densities of slow lorises and tarsiers living sympatrically and studied simultaneously. Despite considerable efforts, we recorded few animals and our density estimates from this Bornean study are low compared with those reported from areas where slow lorises and tarsiers do not live sympatrically. Our encounter rates with Bornean slow lorises are similar to those reported by Nekaris et al. (2008) and Munds et al. (2008), suggesting that slow lorises occur in low densities on Borneo. While low, possibly because of the paucity of data, we were not able to demonstrate a significant difference between slow loris densities on Borneo and that of slow lorises in other areas. Unlike slow

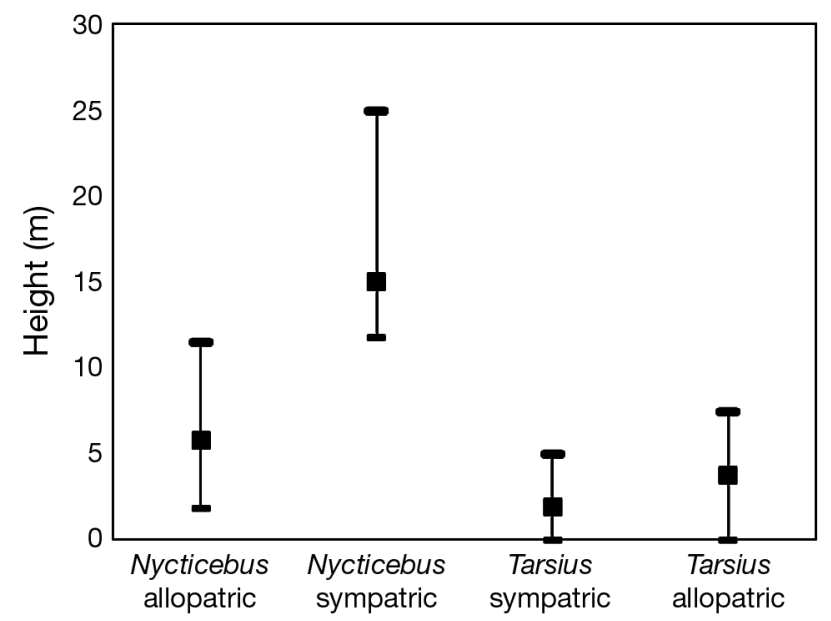

Fig. 2. Use of vertical strata by slow lorises (Nycticebus: 14 studies) and tarsiers (Tarsius: 8 studies) in areas of sympatry and allopatry. Boxes indicate the median of median heights recorded upon first contact, the lower whisker the median of the minimum heights and the upper whisker the median of the maximum heights. See Table 2 for list of studies used 
Table 2. Vertical strata use by slow lorises (Nycticebus) and tarsiers (Tarsius) in areas where they occur allopatrically and sympatrically. Reported are median heights at which individuals were first encountered, with the range in parentheses. n.a.: data not available

\begin{tabular}{|c|c|c|c|}
\hline Species & Area & Height (m) & Source \\
\hline \multicolumn{4}{|c|}{ Slow lorises in allopatry } \\
\hline \multirow[t]{5}{*}{ N. bengalensis } & Northeast India & $5.5(0-11)$ & Radhakrishna et al. (2006) \\
\hline & Northeast India & $8(5-15)$ & Swapna et al. (2008) \\
\hline & Northeast India & $10.0(3.0-16.0)$ & Das et al. (2009) \\
\hline & Thailand & $8(5-10)$ & Pliosungnoen \& Savini (2008 unpubl.) \\
\hline & West Cambodia & $8(1-18)$ & Rogers (2009) \\
\hline \multirow[t]{2}{*}{ N. pygmaeus } & East Cambodia & $5.0(0.5-20.0)$ & Starr et al. (2011) \\
\hline & Vietnam & n.a. $(0.5-12.0)$ & Tan \& Drake (2001) \\
\hline \multirow[t]{3}{*}{ N. coucang } & Thai-Malay Peninsula & n.a. $(1.8-35.0)$ & Wiens \& Zitzmann (2003) \\
\hline & Thai-Malay Peninsula & $1.8(1.8-3.7)$ & Elliot \& Elliot (1967) \\
\hline & Sumatra & $6.0(2.5-7.0)$ & K. A. I. Nekaris \& V. Nijman (unpubl. data) \\
\hline \multirow[t]{2}{*}{ N. javanicus } & West Java & $4.6(4.5-9.5)$ & Collins (2007) \\
\hline & West Java & $4.0(0-10.0)$ & R. Moore \& K. A. I. Nekaris (unpubl. data) \\
\hline \multicolumn{4}{|c|}{ Slow lorises and tarsiers in sympatry } \\
\hline \multirow[t]{2}{*}{ N. menagensis } & South Borneo & $15.0(15.0-20.0)$ & Blackham (2005) \\
\hline & North Borneo & $15.0(8.5-30.0)$ & Present study \\
\hline \multirow[t]{4}{*}{ T. borneanus } & North Borneo & $1.3(0.5-3.0)$ & Present study \\
\hline & North Borneo & $1.0(0-10.7)$ & Crompton et al. (2010) \\
\hline & North Borneo & $2.5(0-5.0)$ & Crompton \& Andau (1986) \\
\hline & Belitung & $2.5(0-5.0)$ & Yustian (2007) \\
\hline \multicolumn{4}{|c|}{ Tarsiers in allopatry } \\
\hline T. lariang & Central Sulawesi & $2.5(0-5.0)$ & Merker (2012) \\
\hline T. spectrum & North Sulawesi & $5.0(0-10.0)$ & MacKinnon \& MacKinnon (1980) \\
\hline T. pumilus & Central Sulawesi & $10(0-20.0)$ & N. Grow (2012 unpubl.) \\
\hline T. dentatus & Central Sulawesi & $2.5(0-5.0)$ & Merker \& Gursky (2012) \\
\hline
\end{tabular}

lorises on Borneo, it appears that tarsiers that live sympatrically with slow lorises do occur in lower densities than their congeners that live outside the geographic range of slow lorises (see Blackham 2005).

The low densities observed in sympatric species could be due to competition (Table 1). Tarsiers and slow lorises share a similar diet, although there are differences, as lorises are omnivorous and tarsiers only eat living prey (Jablonski \& Crompton 1994, Ravosa 1998, Nekaris \& Bearder 2007). Even so, competition for resources, including prey, could be a limiting factor to population growth. Overall, there was a significant difference between the sympatric and allopatric population densities of tarsiers, with an average population density of tarsiers living allopatrically from slow lorises of 159 ind. $\mathrm{km}^{-2}$, and an average population density of species living sympatrically with slow lorises of 16 ind. $\mathrm{km}^{-2}$. It is possible that lorises are predating on tarsiers (Niemitz 1979), which could be impacting the tarsier population. More research is needed to confirm this speculation, but it has been observed before and could be a potential driver of the low population size of tarsiers that are sympatric with lorises. Slow lorises did not show significant differences in density between the allopatric and sympatric populations, although on average the sympatric populations had a lower average population size in comparison with the allopatric species (sympatric: 5 ind. $\mathrm{km}^{-2}$; allopatric: 28 ind. $\mathrm{km}^{-2}$ ).

\section{Microhabitat variability and niche divergence}

The differences in microhabitats could be reducing competition between lorises and tarsiers, as there was a significant difference between the microhabitat structures of the genera. Lorises appear to lack a defined microhabitat, as differences between loris plots and control plots were not significant. Past studies on slow lorises have found that they occupy numerous types of environment, from plantations and other agricultural areas to heavily degraded forests and pristine forests (Elliot \& Elliot 1967, Wiens \& Zitzmann 2003, Radhakrishna et al. 2006, Nekaris et al. 2008). An important limitation for lorises is that they are quadrupedal and are incapable of leaping, thus requiring canopy continuity to move easily throughout the forests, although they can move on 
the ground when necessary (Nekaris \& Bearder 2007). In contrast, tarsiers require dense undergrowth. Studies indicate tarsiers are not capable of adapting to agricultural areas or modified landscapes (e.g. Merker et al. 2005). Populations in anthropogenically modified areas are considerably lower compared with other populations (Merker et al. 2005). Such requirements pose a challenge for tarsiers when confronted with environmental and ecological changes. Competing against an adaptable animal, such as a loris, could be affecting the population size of tarsiers, and may explain why tarsiers are confined to select areas of a forest.

Areas where tarsiers were found lacked the continuity that lorises required, but did provide the necessary substrates for tarsiers: trees with small DBH. Crompton \& Andau (1987) and Niemitz (1984) noted that Bornean tarsiers preferred vertical supports smaller than $4 \mathrm{~cm}$ DBH. These small, vertical substrates allow for easy grasping, which helps with vertical clinging and leaping (Crompton et al. 2010). Tarsiers in our study were observed in trees with an average DBH of $4 \mathrm{~cm}$, and the median DBH in tarsier plots was $5 \mathrm{~cm}$. Conversely, lorises were found in trees with a DBH of $40 \mathrm{~cm}$, and the median DBH values of loris and neutral plots were twice as large as in tarsier plots. The results of the present study indicate that lorises are less selective in their habitats, but do not occur in preferred tarsier habitats as the supports required are not available. This suggests that competition is being avoided because slow lorises are restricted to habitats that have canopy continuity which enables them to move easily.

An additional observed niche divergence is the level of height at which individuals were observed (Table 2). Logically, because Bornean tarsiers prefer trees with a small DBH, they are found at lower levels in the canopy. In our study we observed an average height of $1.8 \mathrm{~m}$ (range 0 to $20 \mathrm{~m}$ ). Slow lorises occupied heights that ranged from the ground to as high as 30+ m (Wiens \& Zitzmann 2003, Nekaris \& Bearder 2007), but until now almost all studies have been conducted on species that do not share height ranges with tarsiers. The median height of trees used by Bornean lorises was $15 \mathrm{~m}$, with a range of 8.5 to $30 \mathrm{~m}$. The Bornean loris range overlaps the range of the tarsiers, but only by $1.5 \mathrm{~m}$. Compared with other $\mathrm{NyC}_{\mathrm{C}}$ ticebus spp., the Bornean lorises do significantly favor higher canopy levels.

This use of higher levels of the canopy sustains a stable co-existence with the Bornean tarsiers, and our results are comparable, although not as detailed, as the classic canopy division study performed in
Gabon on 5 sympatric nocturnal primates (CharlesDominique 1977). These strepsirrhines shared a habitat, but were able to co-exist because of different requirements, which affected their canopy height preferences. In the Gabon study, the Allen's bushbaby Sciurocheirus alleni cameronensis, a vertical clinger and leaper, was found at heights of 1 to $2 \mathrm{~m}$ and on vertical supports of 1 to $15 \mathrm{~cm}$. The potto Perodicticus potto edwardsi, a quadrupedal primate, spent most of its time in the upper canopy (20 to $40 \mathrm{~m}$ ), but was spotted as low as $5 \mathrm{~m}$, and was found on large branches and lianas (Charles-Dominique 1977). Other researchers have had similar results, indicating that height preference can be an outcome of locomotion or ecological needs (Harcourt \& Nash 1986, Fleagle 1999, Heymann \& Buchanan-Smith 2000, Pimley 2002, Bearder et al. 2003).

\section{Suggestions for future studies}

Other niche divergences contributing to the sympatry of these nocturnal primates need to be explored. One is the body size and weight differences. The Bornean loris has a median weight of $420 \mathrm{~g}$ (range 265 to $682 \mathrm{~g}$ ) and an average body length of $260 \mathrm{~mm}$ (R. A. Munds unpubl. data). The western tarsier (all $T$. bancanus ssp.) has a median weight of $115 \mathrm{~g}$ (range 106 to $138 \mathrm{~g}$ ) and an average body length of $160 \mathrm{~mm}$ (Nekaris \& Munds 2010, R. A. Munds unpubl. data). The differences in body size may contribute to differences in metabolic rates and dietary requirements. In the present study we also observed differences in anti-predator strategies. Upon detection, we noted that tarsiers would take flight, quickly leaping from sapling to sapling. Lorises would freeze, sometimes hiding their faces and eyes from the observer. Different flee responses have been observed in sympatric mouse lemurs (Radespiel et al. 2003), galagos (Bearder \& Doyle 1974) and other lorisids (Charles-Dominique 1977).

Data are needed on various aspects of the ecology of these primates to discern how niche divergences are reducing competition. We recognize the limitations of our study, especially in regards to the geographically wide-scale cross-site comparison. Unfortunately, detailed information on microhabitats of these genera is difficult to find. Our small-scale study of these genera is one of the few to provide information on the microhabitat compositions of these species, particularly in terms of tree size (DBH and height). Such information on the other sites that we incorporated in the broader geographic study is not 
easy to obtain. Future studies need to provide this information, as understanding the forest composition of these primates is necessary to create effective conservation action plans. This study provides a first glimpse into how these primates are living sympatrically and confirms that Bornean lorises and tarsiers appear to be living sympatrically by favoring different habitats and canopy heights. In regards to population size, loris populations do not seem to be impacted by the presence of tarsiers. However, tarsier populations are affected by the presence of lorises, and conservationists should consider this when developing conservation action plans for tarsiers. Additionally, microhabitat preferences and sympatric relationships should be considered when establishing conservation statuses and designing future conservation action plans for sympatric tarsiers and lorises.

Acknowledgements. We thank the Economic Planning Unit of Malaysia and the Sabah Wildlife Department for permitting this study. Thanks to D. Stark and L. Schein for manuscript comments. Thank you to N. Roatch and B. Resake for field assistance. Additional thanks goes to M. Boulanger for designing and sharing the map of DGFC/LKWS. We are grateful for the financial support provided by the Primate Society of Great Britain, Primate Action Fund, Primate Conservation Inc., Columbus Zoo and Aquarium, Cleveland Metroparks Zoo and Cleveland Zoological Society, Phoenix Zoo and The Margot Marsh Biodiversity grant. This study adhered to animal handling and observing protocols of the American Society of Mammalogists.

\section{LITERATURE CITED}

Ancrenaz M, Goossens B, Gimenez O, Sawang A, LackmanAncrenaz I (2004) Determination of ape distribution and population size using ground and aerial surveys: a case study with orang-utans in lower Kinabatangan, Sabah, Malaysia. Anim Conserv 7:375-385

Barrett E (1984) The ecology of some nocturnal, arboreal mammals in the rainforests of peninsular Malaysia. $\mathrm{PhD}$ dissertation, University of Cambridge

Bearder SK, Doyle GA (1974) Ecology of bushbabies Galago senegalensis and Galago crassicaudatus, with some notes on their behaviour in the field. In: Martin RD, Doyle GA, Walker AC (eds) Prosimian biology. Duckworth, London, p 109-130

Bearder SK, Ambrose L, Harcourt C, Honess P and others (2003) Species-typical patterns of infant contact, sleeping site use and social cohesion among nocturnal primates in Africa. Folia Primatol 74:337-354

Bearder SK, Nekaris KAI, Curtis DJ (2006) A re-evaluation of the role of vision in the activity and communication of nocturnal primates. Folia Primatol 77:50-71

Blackham G (2005) Pilot survey of nocturnal primates, Tarsius bancanus borneanus (western tarsier) and Nycticebus coucang menagensis (slow loris) in peat swamp forest, Central Kalimantan, Indonesia. MSc thesis, Oxford Brookes University, Oxford
Charles-Dominique P (1977) Ecology and behavior of nocturnal primates. Columbia University Press, New York, NY

> Chen JH, Pan D, Groves CP, Wang YX and others (2006) Molecular phylogeny of Nycticebus inferred from mitochondrial genes. Int J Primatol 27:1187-1200

Collins R (2007) Preliminary study of behaviour and population densities of Nycticebus coucang and N. javanicus in Sumatra and Java, Indonesia. MSc thesis, Oxford Brookes University, Oxford

Coudrat CNZ, Rogers LD, Nekaris KAI (2011) Abundance of primates reveals Samkos Wildlife Sanctuary, Cardamom Mountains, Cambodia as a priority area for conservation. Oryx 45:427-434

Crompton RH, Andau PM (1986) Locomotion and habitat utilization in free-ranging Tarsius bancanus: a preliminary report. Primates 27:337-351

Crompton RH, Andau PM (1987) Ranging, activity rhythms, and sociality in free-ranging Tarsius bancanus: a preliminary report. Int J Primatol 8:43-71

Crompton RH, Blanchard M, Coward S, Alexander R, Thorpe S (2010) Vertical clinging and leaping revisited: locomotion and habitat use in the western tarsier, Tarsius bancanus explored through loglinear modeling. Int J Primatol 31:958-979

- Das N, Biswas J, Das J, Ray PC, Sangma A, Bhattacharjee PC (2009) Status of Bengal slow loris Nycticebus bengalensis (Mammalia: Primates: Lorisidae) in Gibbon Wildlife Sanctuary, Assam, India. J Threat Taxa 1:558-561

Davies G (2002) Primates. In: Davies G (ed) African forest biodiversity. Earthwatch Institute, Oxford, p 99-116

Davison GWH (2006) Rehabilitation and restoration of habitat near the Kinabatangan Wildlife 367 Sanctuary, Sabah Malaysia. International Expert Meeting of Forest Landscape Restoration. www.iucn.org (accessed 30 November 2007)

Elliot O, Elliot M (1967) Field notes on the slow loris. Malaya. J Mammal 48:497-498

Field A (2009) Discovering statistics using SPSS. Sage, Los Angeles, CA

Fleagle J (1999) Primate adaptations and evolution. Academic Press, New York, NY

> Goossens B, Chikhi L, Jalil MF, Ancrenaz M and others (2005) Patterns of genetic diversity and migration in increasingly fragmented and declining orangutan (Pongo pygmaeus) populations from Sabah, Malaysia. Mol Ecol 14:441-456

> Groves CP (1998) Systematics of tarsiers and lorises. Primates 39:13-27

> Groves CP, Shekelle M (2010) The genera and species of Tarsiidae. Int J Primatol 31:1071-1082

- Gursky S (1998) Conservation status of the spectral tarsier, Tarsius spectrum: population density and home range size. Folia Primatol 69:191-203

Gursky S (2007) Tarsiiformes. In: Campbell C, Fuentes A, MacKinnon $K$, Panger M, Bearder SK (eds) Primates in perspective. Oxford University Press, Oxford, p 73-85

Harcourt AH (1999) Biogeographic relationships of primates on South-East Asian islands. Glob Ecol Biogeogr 8:55-61

> Harcourt CS, Nash LT (1986) Species differences in substrate use and diet between sympatric galagos in two Kenyan coastal forests. Primates 27:41-52

> Heymann EW, Buchanan-Smith H (2000) The behavioral ecology of mixed-species troops of callitrichine primates. Biol Rev Camb Philos Soc 75:169-190 
IUCN (2013) IUCN Red List of Threatened Species. www. iucnredlist.org

- Jablonski NG, Crompton RH (1994) Feeding behavior, mastication, and tooth wear in the western tarsier (Tarsius bancanus). Int J Primatol 15:29-59

Johns A (1983) Ecological effects of selective logging in a west Malaysian rainforest. Cambridge University Press, Cambridge

MacKinnon J, MacKinnon K (1980) The behavior of wild spectral tarsiers. Int J Primatol 1:361-379

Merker S (2012) Tarsius lariang. In: Rowe N, Myers M (eds) All the world's primates. www.alltheworldsprimates.org (accessed December 2012)

Merker S, Gursky S (2012) Tarsius dentatus. In: Rowe N, Myers M (eds) All the world's primates. www.allthe worldsprimates.org (accessed December 2012)

Merker S, Yustian I, Muhlenberg M (2005) Responding to forest degradation: Altered habitat use by Dian's tarsier (Tarsius dianae) in Sulawesi, Indonesia. Oryx 39:189-195

Munds RA, Collins R, Nijman V, Nekaris KAI (2008) Abundance estimates of three slow loris taxa in Sumatra $(N$. coucang), Java ( $N$. javanicus) and Borneo (N. menagensis). Int J Primatol 96:902 (Abstract)

Munds RA, Nekaris KAI, Ford SM (2013) Taxonomy of the Bornean loris with new species Nycticebus kayan (Primate, Lorisidae). Am J Primatol 75:46-56

Musser GG, Dagasto M (1987) The identity of Tarsius pumilus, a pygmy species endemic to the montane mossy forests of central Sulawesi. Am Mus Novit 2867:1-53

Nekaris KAI (2003) Observations on mating, birthing and parental care in three taxa of slender loris in India and Sri Lanka (Loris tardigradus and Loris lydekkerianus). Folia Primatol 74:312-336

Nekaris KAI, Bearder SK (2007) The strepsirrhine primates of Asia and mainland Africa: diversity shrouded in darkness. In: Campbell C, Fuentes A, MacKinnon K, Panger M, Bearder SK (eds) Primates in perspective. Oxford University Press, Oxford, p 24-45

Nekaris KAI, Munds R (2010) Using facial markings to unmask diversity: the slow lorises (Primates: Lorisidae: Nycticebus) of Indonesia. In: Gursky S, Supriatna J (eds) The primates of Indonesia. Springer, New York, NY, p 383-396

Nekaris KAI, Nijman V (2007) CITES proposal highlights rarity of Asian nocturnal primates (Lorisidae: Nycticebus). Folia Primatol 78:211-214

Nekaris KAI, Blackham G, Nijman V (2008) Conservation implications of low encounter rates of five nocturnal primate species (Nycticebus sp.) in Southeast Asia. Biodivers Conserv 17:733-747

> Neri-Arboleda I, Stott P, Arboleda NP (2002) Home ranges, spatial movements and habitat associations of the Philippine tarsier (Tarsius syrichta) in Corella, Bohol. J Zool 257:387-402

Niemitz C (1979) Results of a field study of the western tarsier (Tarsius bancanus borneanus Horsefield, 1821) in Sarawak. Sarawak Mus J 27:171-228

Niemitz C (1984) The biology of tarsiers. Gustav Fischer Verlag, New York, NY

- Nijman V, Nekaris KAI (2010) Checkerboard patterns, inter-

Editorial responsibility: Carly Starr,

Gatton, Queensland, Australia specific competition, and extinction: lessons from distribution patterns of tarsiers (Tarsius) and slow lorises (Nycticebus) in insular Southeast Asia. Int J Primatol 31: 1147-1160

Pimley ER (2002) The behavioural ecology and genetics of two nocturnal prosimians: pottos (Perodicticus potto edwardsi) and Allen's bushbabies (Galago alleni cameronensis). PhD dissertation, University of Cambridge, Cambridge

> Radespiel U, Ehresmann P, Zimmermann E (2003) Speciesspecific usage of sleeping sites in two sympatric mouse lemur species (Microcebus murinus and M. ravelobensis) in northwestern Madagascar. Am J Primatol 59:139-151

Radhakrishna S, Goswami AB, Sinha A (2006) Distribution and conservation of Nycticebus bengalensis in northeastern India. Int J Primatol 27:971-982

Ravosa MJ (1998) Cranial allometry and geographic variation in slow lorises (Nycticebus). Am J Primatol 45: $225-243$

Rogers L (2009) Preliminary survey, behavior and ecology of the Bengal slow loris (Nycticebus bengalensis) in Samkos Wildlife Sanctuary, Cambodia. MSc thesis, Oxford Brookes University, Oxford

Roos C (2003) Molekulare Phylogenie der Halbaffen, Schlankaffen, und Gibbons. PhD dissertation, Technische Universität München, Munich

Schwartz JH (2003) How close are similarities between Tarsius and other primates? In: Wright PC, Simons EL, Gursky S (eds) Tarsiers: past, present, and future. Rutgers University Press, New Brunswick, p 50-96

Shekelle M, Salim A (2009) An acute conservation threat to two tarsier species in the Sangihe Island chain, North Sulawesi, Indonesia. Oryx 43:419-426

Shekelle M, Groves CP, Merker S, Supriatna S (2008) Tarsius tumpara: a new tarsier species from Siau Island, North Sulawesi. Primate Conserv 23:55-64

Starr C, Nekaris KAI, Streicher U, Leung L (2011) Field surveys of the threatened pygmy slow loris (Nycticebus pygmaeus) using local knowledge in Mondulkiri Province, Cambodia. Oryx 45:135-142

Sutherland WJ (2002) Mammals. In: Sutherland WJ (ed) Ecological census techniques. Cambridge University Press, Cambridge, p 260-278

Swapna N, Gupta A, Radhakrishna S (2008) Distribution survey of Bengal slow loris Nycticebus bengalensis in Tripura, Northeastern India. Asian Primates J 1:37-40

Tan CL, Drake JH (2001) Evidence of tree gouging and exudate eating in pygmy slow lorises (Nycticebus pygmaeus). Folia Primatol 72:37-39

- Wiens F, Zitzmann A (2003) Social structure of the solitary slow loris Nycticebus coucang (Lorisidae). J Zool 261: $35-46$

Yustian I (2007) Ecology and conservation status of Tarsius bancanus salator on Belitung Island, Indonesia. PhD dissertation, Georg-August-Universität zu Göttingen, Göttingen

Yustian I, Merker S, Supriatna J, Andayani N (2008) Relative population density of Tarsius dianae in man-influenced habitats of Lore Lindu National Park, Central Sulawesi, Indonesia. Asian Primates J 1:10-16

Submitted: May 13, 2013; Accepted: October 16, 2013

Proofs received from author(s): December 13, 2013 